\title{
APLIKASI SELEKSI PENDUKUNG KEPUTUSAN DALAM PROSES PENERIMAAN KARYAWAN MENGGUNAKAN METODE WEIGHT PRODUCT
}

\author{
Tino Muchlisin ${ }^{*}$, Hedy Ismaya ${ }^{2}$, Pria Sukamto ${ }^{3}$ \\ 1*3 Program Studi Teknik Informatika, Sekolah Tinggi Teknologi Muhammadiyah Cileungsi. \\ 2 Program Studi Teknik Informatika, STMIK Bani Saleh \\ 1*,3 Jl. Anggrek No.25, Perum. PTSC, Cileungsi, Bogor, Jawa Barat, Indonesia-16820 \\ 2 Jl. Mayor Madmuin Hasibuan No.68, RT.004/RW.004, Margahayu, Bekasi Timur, Kota Bekasi, Jawa \\ Barat 17113
}

\author{
Informasi Artikel \\ Article History: \\ Submission: 29-05-2020 \\ Revised: 16-06-2020 \\ Accepted: 23-06-2020 \\ Published: 30-06-2020 \\ Kata Kunci: \\ Seleksi, Sistem Pendukung \\ Keputusan, Weight Product.

\section{Keywords:} \\ Decision, Support System, \\ Selection, Weight Product.

$\frac{* \text { Korespondensi: }}{\text { Tino Muchlisin }}$
tinomukhlisin@gmail.com

\begin{abstract}
Abstrak
CV XYZ adalah merupakan sebuah perusahaan yang bergerak dalam bidang washing. Kendala yang ada di perusahaan ini adalah pada saat proses seleksi penerimaan karyawan, Perusahaan ini dalam proses seleksi karyawan tidak memiliki standar yang cukup, karena proses seleksi hanya dengan proses interview saja, Penilaian kelayakan menjadi pekerja di perusahaan hanya berdasarkan pengalaman kerja saja sehingga keputusan yang diambil sering dipengaruhi oleh faktor subyektifitas dari pengambilan keputusan sehingga kualifikasi pekerja tidak sesuai dengan kebutuhan dilapangan, Tujuan dari penelitian ini adalah dibuatnya metode seleksi penerimaan karyawan secara lebih objektif dengan aplikasi pendukung keputusan menggunakan Metode Weight Product (WP) dimana metode ini dapat mengelola berbagai kriteria atau bersifat multi kriteria sehingga bisa menyeleksi banyak kriteria karyawan sesuai kualifikasi yang dibutuhkan. Selanjutnya dibuatkan Sistem Aplikasi Pendukung Keputusan menggunakan database MysQL supaya kriteria dapat disimpan dan diperbaharui sesuai kebutuhan. Dari hasil pengujian sistem dapat menghasilkan data penyeleksian karyawan yang lebih baik. Sehingga Aplikasi Sistem Pendukung Keputusan ini dapat membantu manajemen dalam penyeleksian karyawan.

\section{APPLICATION OF DECISION SUPPORT SELECTION IN EMPLOYEE RECEPTION PROCESS USING THE WEIGHT PRODUCT METHOD}

Abstract
CVXYZ is a company engaged in the field of washing. The obstacle in this
company is that during the employee recruitment selection process, the
company in the employee selection process does not have sufficient
standards, because the selection process is only an interview process, the
appraisal of being a worker in the company is only based on work
experience, so the decisions taken often influenced by the subjective
factor of decision making so that the qualifications of workers are not in
accordance with the needs in the field. The purpose of this study is to
make a more objective method of employee recruitment selection using
decision support applications using the Weight Product Method (WP)
where this method can manage various criteria or are multi criteria so
that they can select many employee criteria according to the
qualifications needed. Furthermore, a Decision Support Application
System was created using a MySQL database so that the criteria can be Infotech: Jurnal Informatika \& Teknologi is licensed under a Creative Commons AttributionNonCommercial 4.0 International License. p ISSN 2722-9378| e ISSN 2722-9386 
stored and updated as needed. From the results of testing the system can produce better employee selection data. So that this Decision Support System Application can help management in selecting employees.

\section{PENDAHULUAN}

Karyawan merupakan salah satu sumber daya yang sangat penting di suatu perusahaan. Perusahaan tidak akan dapat berjalan dan berkembang tanpa adanya karyawan. Kualitas karyawan dengan kualifikasi yang berkualitas dapat dilihat dari proses perekrutan dan penyeleksian penerimaan karyawan seperti dilakukan oleh bagian rekrutmen di HRD Department terutama manajer dalam melakukan seleksi sangat dibutuhkan sejak awal dalam proses penerimaan karyawan baru sangat menentukan keputusan yang diambil [1]. Jika terjadi kesalahan dalam menentukan calon karyawan untuk bekerja, maka sangat besar dampaknya bagi perusahaan, karena berpengaruh langsung terhadap kinerja, produktivitas dan finansial perusahaan.

CV. XYZ yaitu perusahaan yang bergerak dalam bidang pelayanan washing. Pada proses seleksi penerimaan karyawan, CV. XYZ dalam melakukan seleksi karyawan baru, tidak memiliki standar yang cukup sebelum dilakukan uji kompetensi pada bidang produk yang ada diperusahaan, karena proses seleksi dilakukan hanya melalui tahapan interview saja. Dari hasil interview, penilaian hanya menitikberatkan pada pengalaman kerja yang dimiliki oleh calon karyawan sehingga keputusan yang diambil sering dipengaruhi oleh faktor subjektivitas dari pengambil keputusan. Selain itu belum adanya sistem yang dapat membantu manajer sumber daya manusia dalam mengambil keputusan untuk menentukan calon karyawan yang sesuai dengan kualifikasi untuk diterima bekerja.

Berdasarkan uraian di atas, penelitian ini merancang dan implementasikan sistem pendukung keputusan dalam menentukan seleksi penerimaan karyawan baru dengan menggunakan metode weighted product (WP). Aplikasi pendukung keputusan ini adalah sistem informasi yang berbasis komputer yang digunakan sebagai metode dalam membantu manajemen dalam membuat Keputusan.

Adapun kelebihan dari metode Weight product dengan pertimbangan bahwa metode ini dapat menyeleksi lebih cepat dari nilai bobot dari setiap atribut dan selanjutnya dilakukan perangkingan. Jadi dengan harapan metode ini nantinya dapat membantu manajemen dalam seleksi penerimaan karyawan sesuai standar yang dibutuhkan.

\section{METODE}

Lokasi penelitian dilaksanakan di CV. XYZ yang terletak di Gang Asem, Lebak Muncang, Cikuda, Wanaherang, Bogor. Waktu pelaksanaan penelitian ini telah dilaksanakan mulai dari tanggal 15 Februari 2019 sampai dengan 21 September 2019.

\subsection{Aplikasi Seleksi Karyawan}


Aplikasi sistem dalam pengambilan keputusan adalah suatu sistem informasi yang mengolah data secara spesifik pada persoalan karyawan yang bersifat semi terstruktur untuk membantu manajemen dalam pengambilan keputusan [2].

\subsection{Arti Seleksi Karyawan}

Seleksi karyawan adalah proses pemilihan karyawan sesuai kualifikasi pada lowongan pekerjaan yang dibutuhkan oleh suatu Institusi/Perusahaan untuk mencapai kualifikasi yang sesuai dengan kebutuhan lapangan kerja [3].

\subsection{Weighted Product}

Weighted product merupakan sebuah metode penentuan suatu keputusan berdasarkan dari hasil perkalian dengan menghubungkan atribut, dimana atribut yang bersangkutan harus dipangkatkan dahulu untuk mendapatkan rating pada setiap atributnya. Proses tersebut adalah [4],[5],[6],[7],[8] . Tahapan atau langkah-langkah metode weighted product [9],[10].

1. Tentukan kriteria yang menjadi acuan dalam pengambilan keputusan $\mathrm{Ci}, \mathrm{J}=1,2$..n.

2. Menentukan bobot awal masing-masing kriteria. Nilai bobot awal (W) digunakan untuk menunjukkan tingkat kepentingan relatif dari setiap kriteria. Nilai bobot awal ini ditentukan oleh pengambil keputusan yang menentukan tingkat kepentingan relatif setiap kriteria. Ada beberapa cara yang bisa dilakukan untuk menentukan bobot awal.

a) Dengan memberikan nilai parameter untuk setiap kriteria

b) Memberikan bobot antara 0-100 yang berarti tingkat kepentingan setiap kriteria.

3. Lakukan proses normalisasi pada setiap bobot awal dengan membagi setiap nilai $\mathrm{W}_{\mathrm{o}}$ dengan Total Nilai $\mathrm{W}_{\mathrm{i}}$

4. Proses Normalisasi/perbaikan bobot akan menghasilkan nilai $\mathrm{Wi}=1$, dimana nilai $\mathrm{J}=$ $1,2 \ldots . .$. . Yaitu banyak alternatif, dan $\sum W j$ jumlah keseluruhan dari nilai bobot. Nilai normalisasi $\left(\mathrm{W}_{\mathrm{j}}\right)$ dihitung dengan rumus.

$W_{j}=\frac{W j}{\sum W j}$

Didalam rumus jelaskan nilai bobot awal dan total nilai $\mathrm{W}_{\mathrm{i}}$

$\mathrm{W}_{\mathrm{j}} \quad=$ Nilai bobot awal

$\sum \mathrm{W}_{\mathrm{j}} \quad=$ Total nilai $\mathrm{W}_{\mathrm{j}}$

5. Proses menentukan nilai Vektor (S).

$$
\mathrm{M} S_{j}=\prod_{j=1}^{n} X_{i j}{ }^{w j}, i=1,2, \ldots, n
$$

Adapun dari nilai didapat, $\mathrm{S}_{\mathrm{i}}, \mathrm{X}_{\mathrm{ij}}, \mathrm{N}, \mathrm{W}_{\mathrm{i}}$.

$S_{j}=$ Menyatakan alternatif ke-j dianalogikan seperti vektor (S).

$\mathrm{X}_{\mathrm{ij}}=$ Menunjukan nilai pada setiap alternatif yang dimiliki oleh semua kriteria.

$\mathrm{N}=$ Banyaknya kriteria.

$\mathrm{W}_{\mathrm{j}}=$ Hasil normalisasi bobot awal.

Cara mencari Nilai Vektor (S) adalah dengan memangkatkan nilai atribut pada setiap kriteria dengan hasil normalisasi yang mempunyai nilai bobot yang berpangkat 
positif sebagai kriteria benefit dan nilai normalisasi yang berpangkat negatif sebagai kriteria biaya.

6. Cara menentukan nilai Vektor (V)

$$
V_{j}=\frac{\prod_{j=1}^{n} x_{i j}{ }^{w j}}{\prod_{j=1}^{n}\left(x_{j}\right)^{w j}}
$$

Vektor $\mathrm{V}_{\mathrm{j}}$ adalah sebuah preferensi dari alternatif yang digunakan dalam perangkingan dengan cara membagi dari masing-masing nilai vektor.

\subsection{ISO 9126}

ISO 9126 adalah standar internasional untuk uji kualitas evaluasi perangkat lunak. Pertama kali hadir pada tahun 1991, dan di perpanjang tahun 2004. ISO 9126 menghadirkan 3 aspek yang mana kualitas perangkat lunak untuk internal audit, external quality dan quality yang di gunakan ISO 2004. Lebih dari itu model evaluasi software untuk external maupun internal dari kualitas software yang berhubungan atribut. Keuntungan utama dari model ini adalah model dapat diterapkan pada kualitas produk perangkat lunak [11]. Dikatakan perangkat lunak berkualitas jika software mempunyai kriteria yaitu reliability, usability, efficiency, functionally, maintainability dan portability [12].

\section{HASIL DAN PEMBAHASAN}

\subsection{Teknik Analisis}

Dari nilai bobot yang diberikan pada setiap alternatif. Untuk dapat menerima pelamar yang sesuai kualifikasi yang diinginkan perusahaan. Maka nilai kriteria setiap alternatif minimal harus bisa mendekati nilai bobot yang telah diberikan atau bahkan nilai bobot kriteria pada setiap alternatif lebih tinggi lebih baik.

Untuk penilaian masing-masing alternatif diberikan kode A1, A2, A3, A4, A5, A6, A7, A8 dan untuk setiap kriteria diberikan kode K1, K2, K3, K4, K5,K6 dan K7. Dari delapan alternatif tersebut hanya satu alternatif yang akan terpilih menjadi alternatif terbaik. Adapun nilai yang dimiliki masing-masing alternatif dijelaskan pada tabel 1 .

Tabel 1. Data penilaian karyawan

\begin{tabular}{lccccccc}
\hline \multirow{2}{*}{ Karyawan } & \multicolumn{7}{c}{ Kriteria } \\
& K1 & K2 & K3 & K4 & K5 & K6 & K7 \\
\hline A1 & 2 & 1 & 4 & 3 & 3 & 5 & 5 \\
A2 & 2 & 5 & 3 & 4 & 5 & 3 & 2 \\
A3 & 3 & 2 & 3 & 3 & 5 & 1 & 2 \\
A4 & 3 & 5 & 4 & 4 & 5 & 1 & 2 \\
A5 & 3 & 1 & 3 & 3 & 3 & 5 & 5 \\
A6 & 3 & 5 & 4 & 5 & 5 & 3 & 3 \\
A7 & 1 & 5 & 3 & 5 & 5 & 3 & 3 \\
A8 & 2 & 5 & 3 & 5 & 5 & 3 & 3 \\
\hline
\end{tabular}

Kasus pertama untuk penyelesaian masalah dengan menggunakan metode weighted product.

1. Setelah mendapatkan data penilaian dari tabel 1, kemudian dilakukan perbaikan bobot (normalisasi) terlebih dahulu. Bobot awal $W=(3,5,3,4,3,3,3)$ akan 
diperbaiki sehingga total bobot $\sum \mathrm{Wj}=1$

$$
\begin{aligned}
& W_{1}=\frac{3}{3+5+3+\frac{4}{5}+3+3+3}=0,12500 \\
& W_{2}=\frac{3}{3+5+3+4+3+3+3}=0,20833 \\
& W_{3}=\frac{3}{3+5+3+\frac{4}{4}+3+3}=0,12500 \\
& W_{4}=\frac{3}{3+5+3+\frac{4}{3}+3+3+3}=0,16666 \\
& W_{5}=\frac{3}{3+5+3+4+3+3+3}=0,12500 \\
& W_{6}=\frac{3}{3+5+3+4+3+3+3}=0,12500 \\
& W_{7}=\frac{3+5+3+3+3+3}{3+5+3+4+3+3}=0,12500
\end{aligned}
$$

2. Perhitungan vector $S$ dan vector $V$ dan hasil dari perhitungan tersebut seperti pada tabel 2.

Tabel 2. Peringkat alternatif terbaik

\begin{tabular}{clcc}
\hline Kode & \multicolumn{1}{c}{ Nama } & Nilai & Peringkat \\
\hline A1 & Kandi & 0,07612 & Ke-8 \\
A2 & Herman & 0,13725 & Ke-3 \\
A3 & Amrido & 0,13045 & Ke-6 \\
A4 & Eko Budiarso & 0,17170 & Ke-1 \\
A5 & Khaerul Khafidz & 0,07725 & Ke-7 \\
A6 & Saeful Bahri & 0,14766 & Ke-2 \\
A7 & Asep Jidoy & 0,12417 & Ke-5 \\
A8 & Ahmid & 0,13541 & Ke-4 \\
\hline
\end{tabular}

\subsection{Use Case diagram}

Use Case diagram digunakan untuk menggambarkan pengguna aplikasi dan aktivitas apa saja yang dapat dilakukan oleh pengguna aplikasi. Pengguna sebagai aktor sedangkan aktivitasnya sebagai use case. Gambaran use case diagram sistem pendukung keputusan seleksi penerimaan karyawan sesuai gambar 1. 
Aplikasi Seleksi Pendukung Keputusan Dalam Proses Penerimaan Karyawan Menggunakan Metode

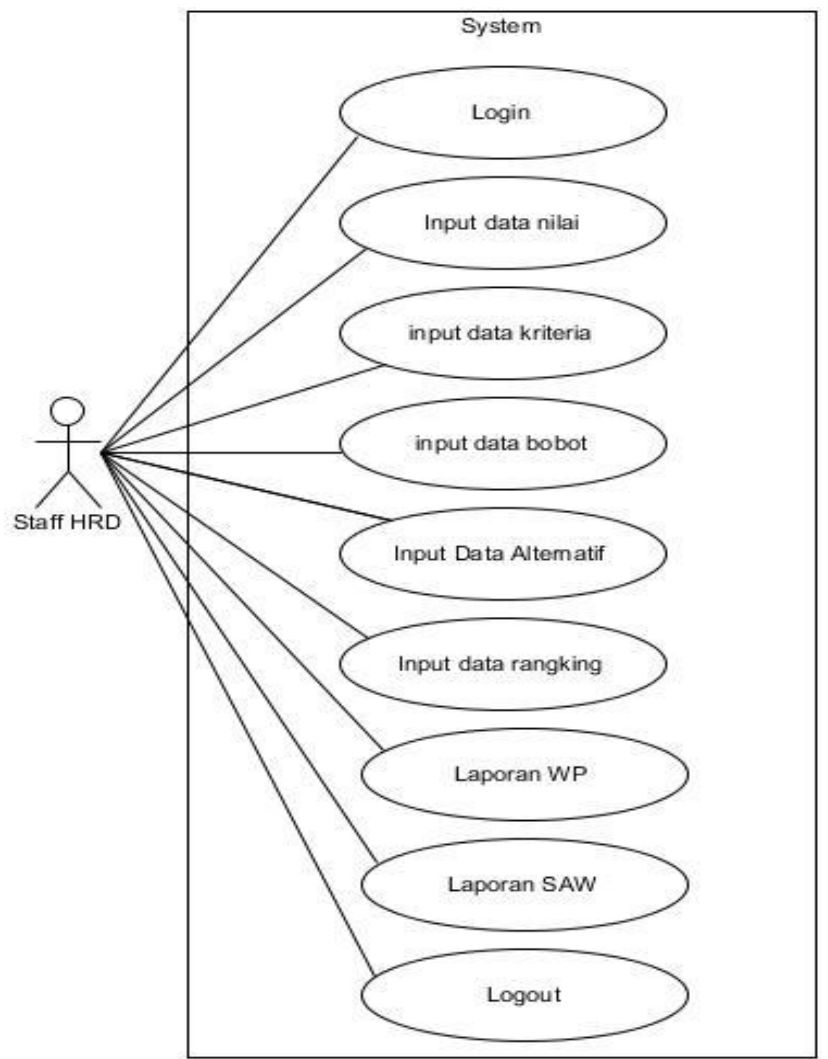

Gambar 1. Use Case Diagram Seleksi Penerimaan Karyawan

\subsection{Class Diagram}

Class diagram digunakan untuk menunjukan interaksi antar kelas dalam sistem. Kelas mengandung informasi dan tingkah laku yang berkaitan dengan informasi tersebut. Berikut adalah rancangan class diagram yang digunakan untuk membangun sistem pendukung keputusan untuk seleksi penerimaan karyawan

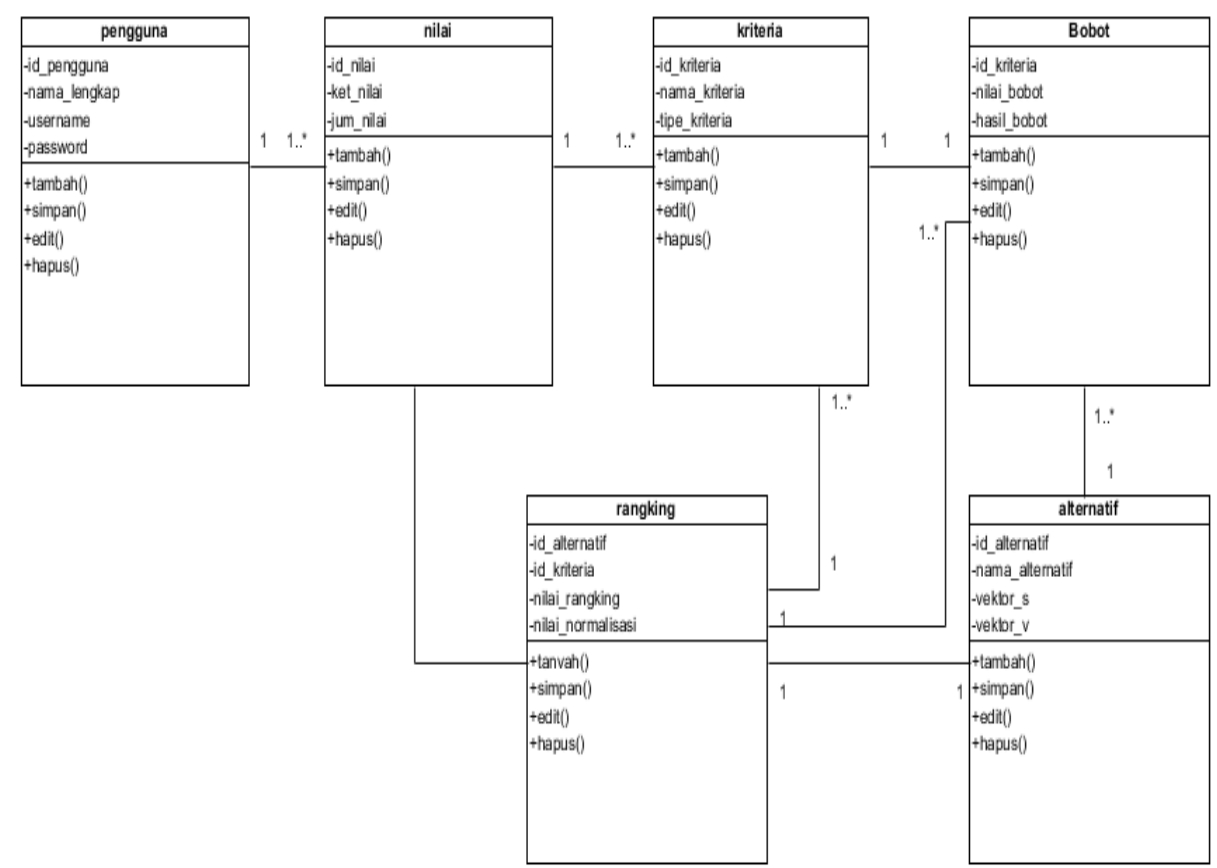

Gambar 2. Class diagram sistem pendukung keputusa seleksi penerimaan karyawan 
Implementasi sistem pendukung keputusan pada seleksi penerimaan karyawan merupakan tahapan dari sistem yang dirancang sehingga menjadi sistem yang dapat dioperasikan dan digunakan oleh user. Dimana metode yang digunakan dalam sistem tersebut adalah weight product (WP).

\subsection{Kebutuhan Perangkat Lunak (software) dan Perangkat Keras (hardware)}

Untuk membangun dan perancangan aplikasi sistem pendukung keputusan seleksi penerimaan karyawan ini menggunakan spesifikasi perangkat keras dan perangkat lunak.

a. Perangkat lunak (software)

- Sistem operasi menggunakan Windows 10 Enterprise 64 bit.

- Database yang digunakan adalah MysQL

- Bahasa pemrograman yang digunakan adan PHP

- Core editor yang digunakan adalah sublime text

b. Perangkat keras (hardware)

- Laptop ASUS X441U

- Processor intel (R) Core (TM) i3 6006U CPU @ 2.00GHz 1.99GHz

- Memory RAM 4GB

- Harddisk 500GB

\subsection{Tampilan Aplikasi}

Tampilan aplikasi merupakan hasil dari aplikasi yang sudah dibuat berupa aplikasi sistem pendukung keputusan seleksi penerimaan karyawan dengan menggunakan metode weighted product (WP).

\subsubsection{Tampilan Form Login}

Tampilan form login menampilkan form yang digunakan untuk dapat masuk kedalam aplikasi dengan cara memasukkan username dan password.

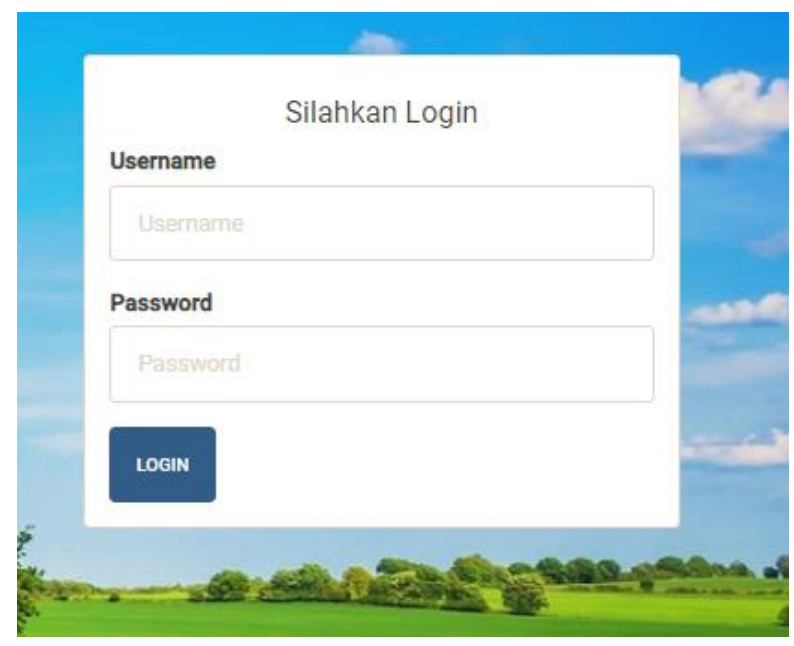

Gambar 3. Tampilan Form Login

\subsubsection{Tampilan Halaman Utama}

Tampilan halaman utama adalah tampilan awal setelah melakukan proses login. Pada halaman utama terdapat beberapa menu yang dapat dilakukan oleh user. 
Aplikasi Seleksi Pendukung Keputusan Dalam Proses Penerimaan Karyawan Menggunakan Metode Weight Product

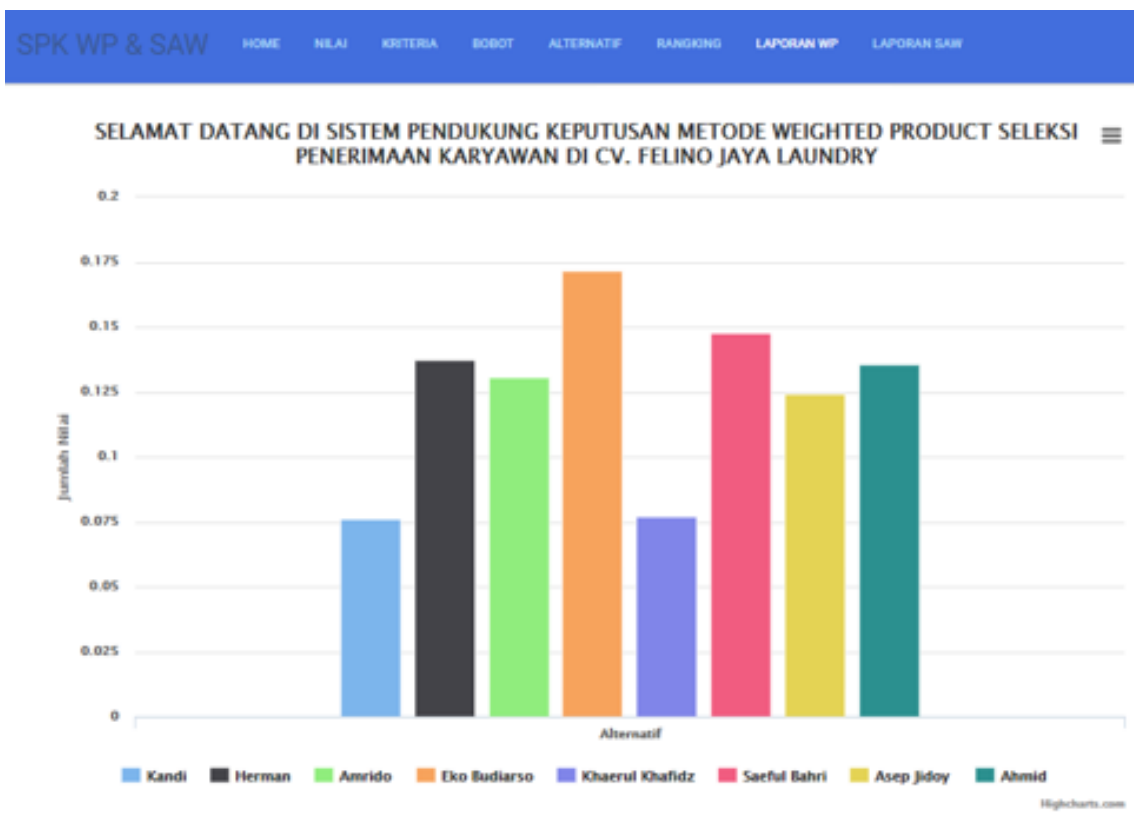

Gambar 4. Tampilan halaman utama

\subsubsection{Tampilan halaman laporan}

Pada tampilan menu laporan WP, user akan diperlihatkan hasil akhir perhitungan SPK seleksi penerimaan karyawan dengan menggunakan metode weighted product dan dapat melakukan proses cetak laporan.

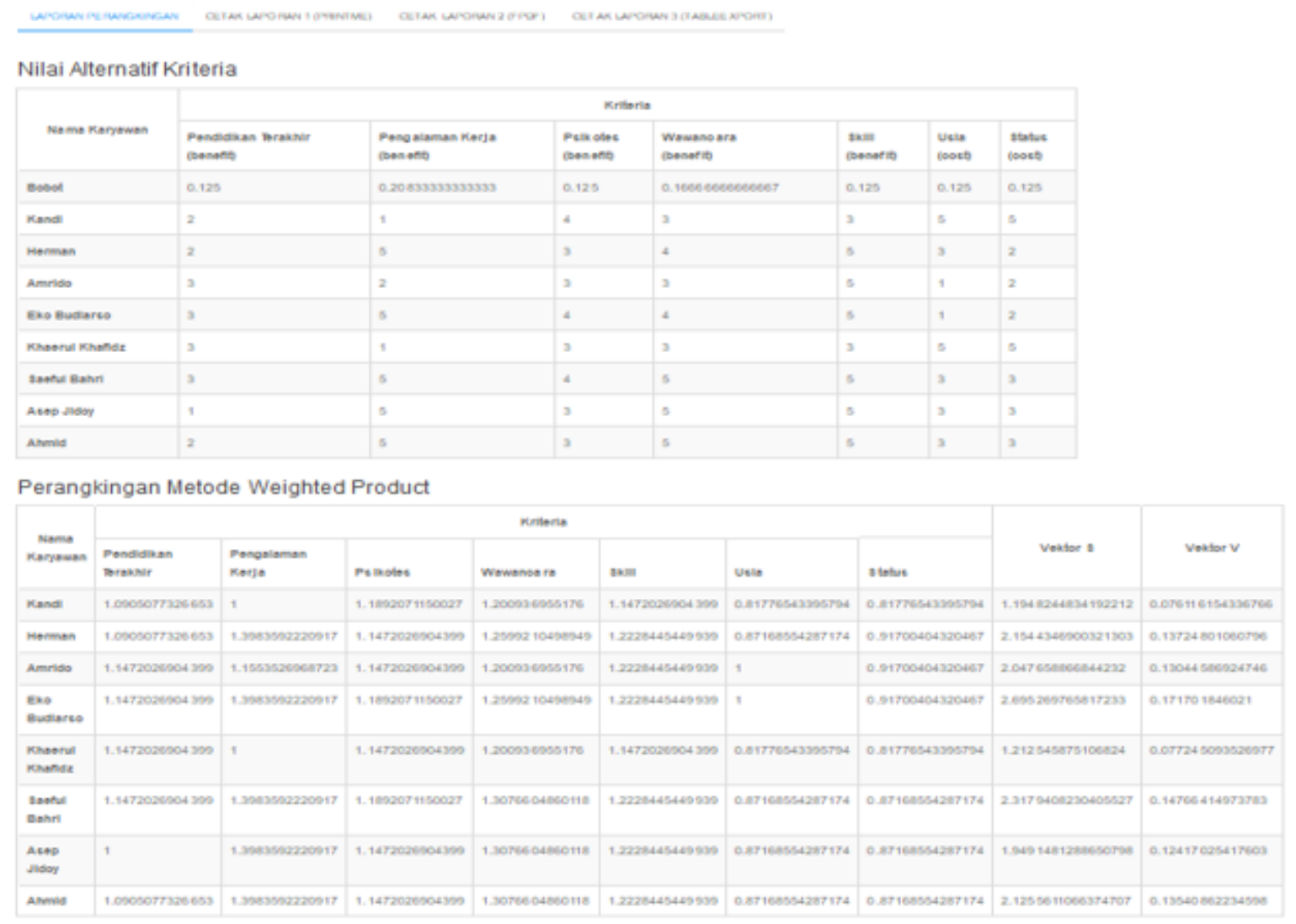

Gambar 5. Tampilan halaman laporan 


\subsection{Pengujian Aplikasi}

Pengujian aplikasi merupakan suatu investigasi yang dilakukan untuk mendapatkan informasi mengenai kualitas dari produk yang sedang diuji. Untuk mengevaluasi dan menetapkan kualitas sebuah perangkat lunak, pengujian aplikasi ini menggunakan 6 aspek yang terdapat pada ISO 9126 yaitu reliability, usability, efficiency, functionally, maintainability dan portability.

\section{Factor Functionality}

Pada faktor functionality terdiri dari 3 pertanyaan, berdasarkan hasil perhitungan dengan menggunakan skala likert. Pengujian ini berfungsi untuk mengetahui fungsionalitas dari sistem pendukung keputusan seleksi penerimaan karyawan. Dari 20 responden yang menjawab sangat baik sebanyak $10 \%$, menjawab baik $25 \%$, menjawab cukup 16\%, menjawab kurang 5\% dan menjawab sangat kurang 4\%. Berikut ini adalah gambar diagram persentase responden berdasarkan faktor functionality.
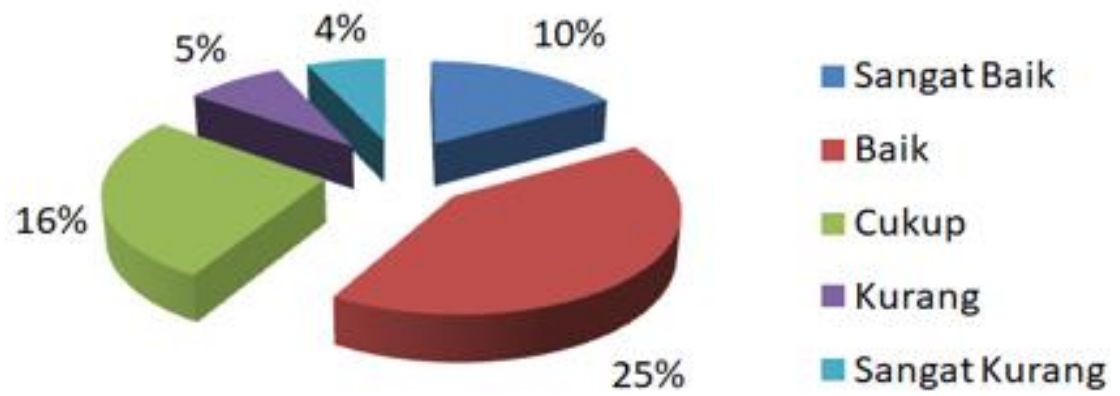

Gambar 6. Diagram functionality

Perhitungan nilai persentase dari skor hasil pengumpulan data untuk faktor functionality.

Jumlah skor hasil pengumpulan data $=212$

Jumlah Jawaban dari 20 responden $=60$

Nilai rata-rata $\quad=\frac{212}{60}=3,53$
Nilai Persentase $=\frac{3,53}{3} \times 100 \%=70,67 \%$

\section{Faktor Reliability}

Pada faktor reliability terdapat 2 pertanyaan berdasarkan hasil perhitungan dengan menggunakan skala likert. Pengujian ini berfungsi untuk mengetahui kehandalan dari sistem pendukung keputusan seleksi penerimaan karyawan. Dari 20 responden yang menjawab sangat baik sebanyak 4\%, menjawab baik 10\%, menjawab cukup 14\%, menjawab kurang 10\% dan menjawab sangat kurang 2\%. Gambar 5 Diagram persentase responden berdasarkan faktor reliability. 
Aplikasi Seleksi Pendukung Keputusan Dalam Proses Penerimaan Karyawan Menggunakan Metode

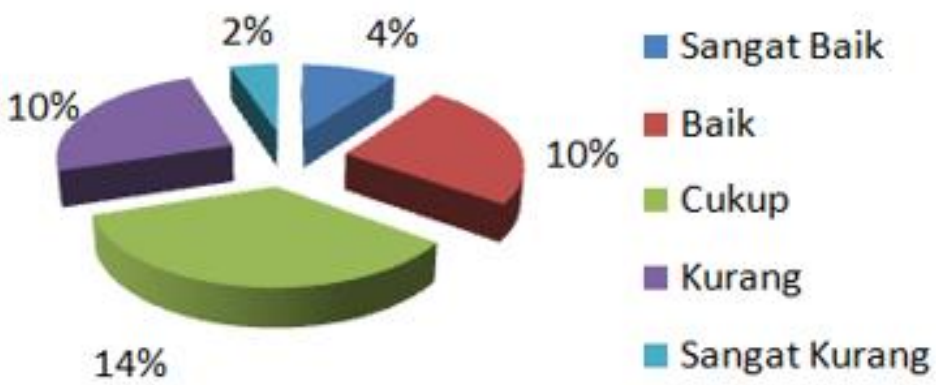

Gambar 7. Diagram Reliability

Berikut perhitungan nilai persentase dari skor hasil pengumpulan data untuk faktor reliability, didapat nilai dalam perhitungan,

Jumlah skor hasil pengumpulan data $=124$

Jumlah Jawaban dari 20 responden $=40$

Nilai rata-rata $=\frac{124}{40}=3,10$
Nilai persentase $\quad=\frac{3,10}{5} \times 100 \%=62 \%$

Berdasarkan perhitungan di atas faktor reliability memiliki persentase sebesar $62 \%$ dengan demikian dapat dinyatakan bahwa skala baik.

\section{Faktor Usability}

Pada faktor usability terdapat 5 pertanyaan berdasarkan hasil perhitungan dengan menggunakan skala likert. Pengujian ini berfungsi untuk mengetahui kebergunaan dari sistem pendukung keputusan penerimaan karyawan. Dari 20 responden yang menjawab sangat baik sebanyak 10\%, menjawab baik 34\%, menjawab cukup 41\%, menjawab kurang 13\% dan menjawab sangat kurang 2\%.

Berikut ini adalah gambar diagram persentase responden berdasarkan faktor usability.

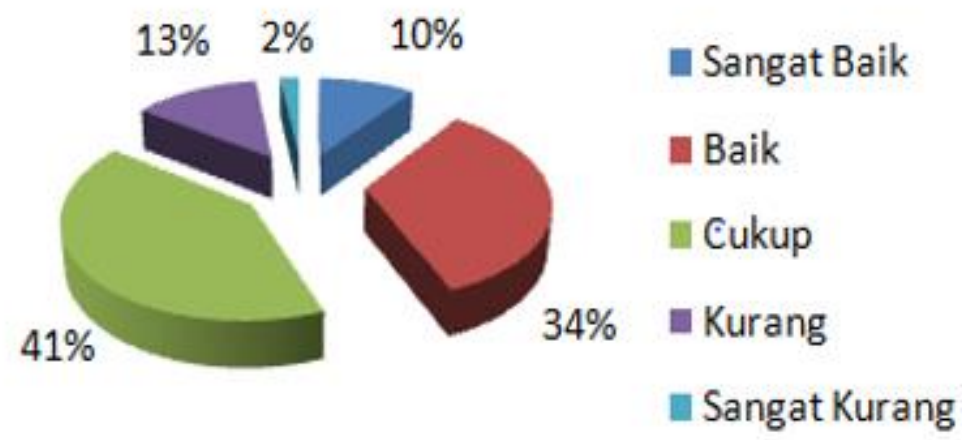

Gambar 8. Diagram usability

Perhitungan nilai persentase dari skor hasil pengumpulan data untuk faktor usability.

- Jumlah skor hasil pengumpulan data $=337$

- Jumlah Jawaban dari 20 responden $=100$

- $\quad$ Nilai rata-rata $=\frac{337}{100}=3,37$ 
- $\quad$ persentase skor $=\frac{3,37}{5} \times 100 \%=67,40 \%$

Berdasarkan perhitungan di atas faktor usability memiliki persentase sebesar $67.40 \%$ dengan demikian dapat dinyatakan bahwa skala baik.

\section{Faktor Efficiency}

Pada faktor efficiency terdapat 3 pertanyaan berdasarkan hasil perhitungan dengan menggunakan skala likert. Pengujian ini berfungsi untuk mengetahui efisiensi sistem pendukung keputusan penerimaan karyawan. Dari 20 responden yang menjawab sangat baik sebanyak $11 \%$, menjawab baik $21 \%$, menjawab cukup $23 \%$ dan menjawab kurang $2 \%$ dan menjawab sangat kurang 3\%. Gambar 7 diagram persentase responden berdasarkan faktor efficiency.
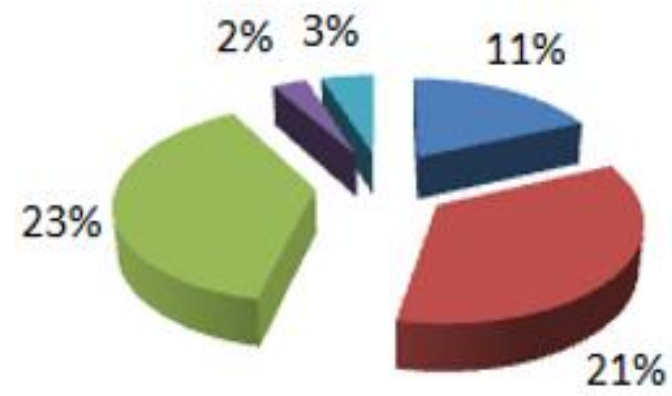

\section{Sangat Baik}

Baik

Cukup

Kurang

Sangat Kurang

Gambar 9. Diagram efficiency

Perhitungan nilai persentase dari skor hasil pengumpulan data untuk faktor efficiency.

- Jumlah skor hasil pengumpulan data $=215$

- Jumlah Jawaban dari 20 responden $=60$

- Nilai rata-rata $=\frac{215}{60}=3,58$

- Persentase skor $=\frac{3,58}{5} \times 100 \%=71.67 \%$

Berdasarkan perhitungan di atas faktor efficiency memiliki persentase sebesar $71.67 \%$ dengan demikian dapat dinyatakan bahwa skala baik.

\section{Faktor Maintainability}

Pada faktor maintainability terdapat 2 pertanyaan berdasarkan hasil perhitungan dengan menggunakan skala likert. Pengujian ini berfungsi untuk mengetahui seberapa jauh recover sistem pendukung keputusan penerimaan karyawan. Dari 20 responden yang menjawab sangat baik sebanyak 7\%, menjawab baik 24\%, menjawab cukup 4\%, menjawab kurang 2\% dan menjawab sangat kurang 3\%.

Gambar 8 diagram persentase responden berdasarkan faktor maintainability. 
Aplikasi Seleksi Pendukung Keputusan Dalam Proses Penerimaan Karyawan Menggunakan Metode

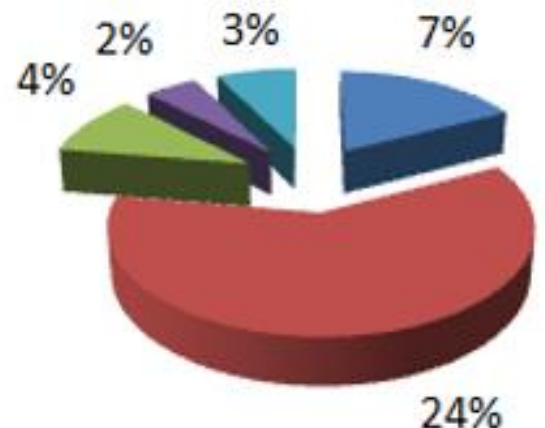

Sangat Baik

Baik

Cukup

Kurang

Sangat Kurang

Gambar 10. Diagram maintainability

Perhitungan nilai persentase dari skor hasil pengumpulan data untuk faktor maintainability.

- Jumlah skor hasil pengumpulan data $=150$

- Jumlah Jawaban dari 20 responden $=40$

- $\quad$ Nilai rata-rata $=\frac{150}{40}=3,75$

- Persentase skor $=\frac{3,75}{5} \times 100 \%=75 \%$

Berdasarkan perhitungan di atas faktor maintainability memiliki persentase sebesar 75\% dengan demikian dapat dinyatakan bahwa skala baik.

\section{Faktor Portability}

Pada faktor portability terdapat 3 pertanyaan berdasarkan hasil perhitungan dengan menggunakan skala liker. Pengujian ini berfungsi untuk mengetahui seberapa mudah instalasi sistem pendukung keputusan penerimaan karyawan. Dari 20 responden yang menjawab sangat baik sebanyak 8\%, menjawab baik 21\%, menjawab cukup 26\%, menjawab kurang 4\%, dan menjawab sangat kurang 1\%. Gambar 9 diagram persentase responden berdasarkan faktor portability.

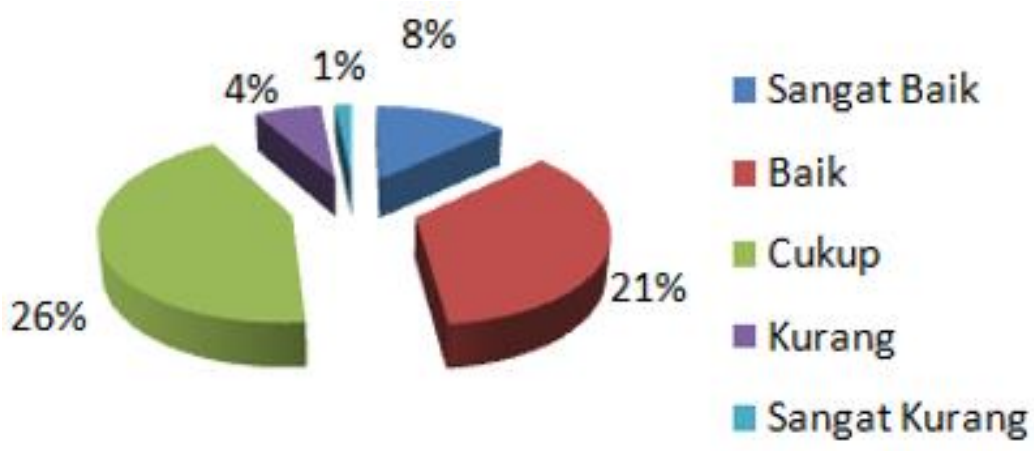

Gambar 11. Diagram portability

Perhitungan nilai persentase dari skor hasil pengumpulan data untuk faktor portability.

- $\quad$ Jumlah skor hasil pengumpulan data $=211$

- Jumlah Jawaban dari 20 responden $=60$ 
- $\quad$ Nilai rata-rata $=\frac{211}{60}=3,52$

- $\quad$ Presentasi skor $=\frac{3,52}{5} \times 100 \%=70,33 \%$

Berdasarkan perhitungan di atas faktor portability memiliki persentase sebesar 70.33\% dengan demikian dapat dinyatakan bahwa skala baik. Dari hasil perhitungan uji kualitas semua faktor di atas, maka dapat dilihat pada tabel 1.

Tabel 3. Hasil perhitungan uji kualitas.

\begin{tabular}{llcccc}
\hline No & Faktor & Rata-rata & $\begin{array}{c}\text { Skor } \\
\text { tertinggi }\end{array}$ & $\begin{array}{c}\text { Hasil } \\
\text { persentase } \\
\%\end{array}$ & Keterangan \\
\hline 1 & Fungsionality & 3,53 & 5 & 70,67 & Baik \\
2 & Reliability & 3,10 & 5 & 62 & Baik \\
3 & Usability & 3,37 & 5 & 67,40 & Baik \\
4 & Efficiency & 3,58 & 5 & 71,67 & Baik \\
5 & Maintainability & 3,75 & 5 & 75 & Baik \\
6 & Portability & 3,98 & 5 & 70,33 & Baik \\
\hline
\end{tabular}

Secara keseluruhan persentase uji kualitas software sistem pendukung keputusan untuk seleksi penerimaan karyawan dengan metode weighted product.

\section{SIMPULAN}

$$
\begin{aligned}
\text { Rata-rata } & =\frac{70,67+62+67,40+71,67+75+70,33}{6} \\
& =\frac{417,07}{6}=69,51 \%
\end{aligned}
$$

Dari hasil analisis, perancangan, implementasi dan pengujian pada aplikasi sistem pendukung keputusan untuk seleksi karyawan dengan menggunakan metode Weighted Product di CV. XYZ menghasilkan kualifikasi nilai seleksi karyawan sesuai klasifikasi pada yang dibutuhkan perusahaan, selanjutnya sistem diadakan pengujian dengan ISO 9126 menghasilkan performance yang cukup baik yaitu 69,51\% dan efesiensi 71.67\% sehingga bisa digunakan sebagai alat bantu oleh manajemen dalam seleksi penerimaan karyawan yang sesuai kompetensi yang dibutuhkan.

\section{DAFTAR PUSTAKA}

[1] Saihudin, Manajemen Sumber Daya Manusia. Ponorogo: Uwais Inspirasi Indonesia, 2019.

[2] Diana, Metode \& Aplikasi Sistem Pendukung Keputusan. Yogyakarta: Deepublish, 2018.

[3] D. Nofriansyah, Konsep Data Mining Sistem Pendukung Keputusan. Yogyakarta: Deepublish.

[4] D. Nofriansyah, Multi Kriteria Decision Making (MCDM) Pada Sistem Pendukung Keputusan. Yogyakarta: Deepublish, 2017.

[5] D. M. Khairina, D. Ivando, and S. Maharani, "Implementasi Metode Weighted Product Untuk Aplikasi Pemilihan Smartphone Android," Infotel, vol. 8, no. 1, p. ISSN : 2085-3688; e-ISSN : 2460-0997, 2016.

[6] M. N. H. Siregar, "Implementasi Weight Product Model (Wpm) Dalam Menentukan 
Pemilihan Sepeda Motor Sport Berbasis Spk," Klik - Kumpul. J. Ilmu Komput., vol. 4, no. 1, p. 59, 2017.

[7] R. Roni, S. Sumijan, and J. Santony, "Metode Weighted Product dalam Pemilihan Penerima Beasiswa Bagi Peserta Didik," J. RESTI (Rekayasa Sist. dan Teknol. Informasi), vol. 3, no. 1, pp. 87-93, 2019.

[8] A. Setyawan, F. Y. Arini, and I. Akhlis, "Comparative Analysis of Simple Additive Weighting Method and Weighted Product Method to New Employee Recruitment Decision Support System (DSS) at PT. Warta Media Nusantara," Sci. J. Informatics, vol. 4, no. 1, pp. 34-42, 2017.

[9] S. Lestari, "Penerapan Metode Weighted Product Model Untuk Seleksi Calon Karyawan," J. Sist. Inf., vol. 5, no. 1, pp. 540-545, 2013.

[10] N. Nurjannah, Z. Arifin, and D. M. Khairina, "Sistem Pendukung Keputusan Pembelian Sepeda Motor Dengan Metode Weighted Product," Inform.

Mulawarman J. Ilm. Ilmu Komput., vol. 10, no. 2, p. 20, 2015.

[11] H. Wicaksono, "Audit Kualitas Software ERP Axapta Menggunakan Standar," J. IIm. Bina Insa. [Terhubung berkala], p.

http://library.binus.ac.id/eColls/eThesisdoc/Bab2H, 2016.

[12] T. N. Sari, "Analisis Kualitas Dan Pengembangan Sistem Informasi Akademik Berbasis Web Menggunakan Standard Iso 9126," JIKO (Jurnal Inform. dan Komputer), vol. 1, no. 1, pp. 1-7, 2016. 